\title{
Impact of Conservation Measures over Mangrove Forest-dependent Community: A Qualitative Study Using Human Rights Lens
}

\author{
Noor Kutubul Alam Siddiquee 12 * \\ 1. Affiliation 1- Subjective Affiliation: Regional Human Rights Research Initiative 2019, Raoul Wallenberg \\ Institute of Human Rights and Humanitarian Law (RWI), siddiquee.nka@gmail.com \\ 2. Present Affiliation: WHO SEARO Region Fellow, siddiquee.nka@gmail.com \\ * Correspondence: siddiquee.nka@gmail.com; Tel.: +880 1964451002
}

\begin{abstract}
Background and Research Highlights: Despite all the concerns and initiatives, natural resources like forest, as well as biodiversity are decreasing at an alarming rate worldwide. Conservation is considered as one of the major tools to prevent such loss and rapid degradation. Evidence around the world shows the adverse effects of conservation laws and policies over indigenous peoples and other local communities.
\end{abstract}

Objectives: This study was conducted in one of the forest-dependent communities situated in Sundarban (world's largest mangrove forest) to understand the impact of conservation laws and policies on their livelihood.

Materials and Methods: A qualitative methodology was designed to collect data, using focus group discussions and case study with community people, and individual interviews with the personnel from NGOs and relevant government departments.

Findings: Strict conservation policies and restriction in accessing forest resources made lives and livelihoods of local community insecure and unstable, thus putting the community in a vulnerable situation. The had to leave their traditional mode of income and look for alternative livelihood options. Almost no evidence was found in relation to upkeeping their rights in conservation activities. Prohibited movement, provision of punishment for entering into the forest without proper permission and struggles in everyday life were some of the highlighted issues. They had no participation in conservation activities, management of alternative livelihood options, and even they were not sensitized before putting restrictions. Although they had a history of emotional and physical attachment with the forest, existing activities did not consider these issues. In addition, corruption and abuse of power by law enforcement agencies towards the local community intensified the sufferings.

Conclusion: This study argues that the realization of human rights in conservation activities and sensitization of the implementing stakeholders are prerequisite for ensuring sustainability of both biodiversity and the affected people.

Keywords: conservation; biodiversity; human rights; livelihood; forest-dependent community; impact 


\section{Introduction}

The conservation and protection of nature and natural resources is a noteworthy issue both for the sustainability of the environment and full enjoyment of human rights, including the rights to life, decent livelihood, health, safety, water, habitat, property, and development [1,2]. Unfortunately, degradation of natural resources, as well as loss of biodiversity and a loss of environmental balance around the world is happening at an alarming rate [3]. For example, forest is one of the major victims of this degradation despite its diverse functions like preventing global warming, land conservation, securing water sources; minimizing negative impacts of climate change; creating natural environs essential for human existence, and most notably comprising of more than 80 percent of the world's terrestrial biodiversity can be found in forest [4-7]. According to the available data of Global Forest Watch, tree cover loss around the world in 2016 was 29.7 million hectares in total, much higher than previous years [8]. According to the World Bank study, the world lost 502,000 square miles (1.3 million square kilometers) of forest between 1990 and 2016 [9]. Every year the world has less forested area due to factors like development projects, constructing habitat, building industries, and climate change to name a few. Although monoculture of exotic trees reduces biodiversity, it still replaces old-growth forests that help to preserve biodiversity, such as slowing down the rate of warming during summer, ensuring stability of temperature, and reducing radiation $[10,11]$.

There are plenty of reasons behind this fatal degradation. One of the key factors behind this degradation is human mobility and excessive pressure over natural resources. Nkonya et al. (2011) and Lambin et al (2001) stated biophysical causes and unsustainable resource management practices for natural resource degradation [12,13]. They also mentioned population density, poverty, land succession mechanism, land use pattern, infrastructural development, industrial flourish as well as policies and general government effectiveness as underlying causes. Zhu and Li (2007) described this phenomenon from a different perspective. They argued that degradation of natural resource was the result of interactions among environmental, social, economic, cultural, and political forces [14].

Halting biodiversity loss and ecosystem degradation forest conservation has become a major concern for nation states and global stakeholders [15]. Forest conservation primarily involves the maintenance of the natural resources that are beneficial for both human beings and environment equilibrium. One of the foremost/main global efforts is the expansion of the totality of protected areas (PAs) as emphasized in the Convention on Biological Diversity (CBD). CBD was adopted at the Earth Summit in 1992 to protect biodiversity and ensure sustainable use of biodiversity and fair distribution of the benefits derived from natural resources [16]. Other two conventions adopted during the United Nations Conference on Environment and Development (UNCED) in 1992 are the United Nations Framework Convention on Climate Change (UNFCCC) and the Convention to Combat Desertification. i Both the documents urge all countries to develop comprehensive approaches towards protection, conservation, management, and utilization of forests and its resources to secure and fulfill socio-economic and environmental needs of the present and future generations. Furthermore, the 2030 Agenda for Sustainable Development and the Paris Agreement on Climate Change also emphasize on reversing the degradation of natural resources like forest [15]. Goal 15 of Sustainable Development Goals (SDGs) aims to "protect, restore and promote sustainable use of terrestrial ecosystems, sustainably manage forests, combat desertification, halt and reverse land degradation and halt biodiversity loss". It should be noted that forests contribute to achieving other SDGs like- Goal 2, 3 and 6.ii There are seven other multilateral agreements relevant to forest conservation and biodiversity lost prevention. These conventions include Ramsar Convention, World Heritage Convention, Convention on International Trade in Endangered Species, Vienna Convention, Indigenous and Tribal Peoples Convention, International Tropical Timber Agreement and Agreement Establishing the World Trade Organization.iii

Forest degradation and forest cover loss are also occurring in Bangladesh at a faster pace. Reddy et al. (2016) estimated based on remote sensing data that forest area declined from 1.65 Mha in 1975 to 1.40 Mha in 2014. The same study also found changes in forest canopy density, i.e. indicating forest degradation. According to the Forestry Department of Government of Bangladesh, 
the reasons behind this degradation are diverse including clearance of forest land; use of forest resources for human settlement, timber, fuel wood, and housing materials; unsustainable forest management practices; poor governance; illegal logging; and natural causes [17]. A number of major strategies and measures are being implemented in Bangladesh to prevent forest degradation and biodiversity loss. Some of the major ones are the National Conservation Strategy (NCS), the Coastal and Wetland Biodiversity Management, the Integrated Coastal Zone Management (ICZM), the National Biodiversity Strategy and Action Plan, the Conservation and management of medicinal plants, the Sustainable Environment Management Programme (SEMP), the Sundarban Biodiversity Conservation Programme, and the Forest Resources Management [18]. In addition to the aforementioned, the concept of protected areas (PAs) is also gaining importance as an effective way to save natural resources. Unfortunately, the socio-economic impacts of protected forests areas on forest-dependent communities are too high [18]. That is, excluding the local people from conservation measures, restricting their access, and granting government full controlling authority may violate dependent community's rights and may lead to conflicting situations and poor/undesirable outcomes [19,20]. For example, Dewan (2019) described the conservation activities on indigenous peoples in protected areas as eviction and limiting the access of forest dependent people (according to Dewan (2019) conservation activities could result in forced evictions of indigenous people and limited or deprivation of ...) [21].

Although conservation measures are primarily for the protection of biodiversity and human welfare, sometimes outcomes of such measures may adversely affect the lives of dependent communities by restricting their access to resources and, in extreme cases, causing evictions $[15,22]$. Evidence shows that lack of realization of people's rights often leads to contentious incidents. Insufficient understanding of local socio-political conditions, lack of recognition of community development needs, displacing local communities from their traditional lands, putting restriction in their access to resources, and providing inadequate or no compensation can make them hostile towards the conservation efforts $[23,24]$. At the same time, gender perspectives also need to be incorporated in conservation measures as conservation might have different impacts over dependent community on the basis of gender. Men and women living in protected areas have different roles. For effective participation and sustainable use of natural resources, it is important to realize the gender-based differences in roles and effects [25]. Global community is now considering the role of conservation initiatives by taking all the dynamics into account towards upkeeping the rights of people around the world with utmost importance [26,27].

The complexities between forest conservation and human rights raise the question of maintaining functional balance, which leads to bigger questions like the nature of changing livelihood pattern of forest-dependent communities, compliance with national and international human rights frameworks and so on. This article/study attempts to explore to what extent forest and biodiversity conservation laws and policies violate or upkeep the rights of forest-dependent communities based on the evidence of a forest-dependent community in Bangladesh. The specific questions this study wanted to explore include:

- How the life of forest-dependent people in Bangladesh is changing as a result of the protected forest areas laws and policies.

- To what extent human rights issues and approaches for the forest-dependent communities fit with the context?

\section{Conceptual Framework: Linking Conservation Measures with Human Rights}

Since indigenous people and local communities have long-term indispensable socio-economic and cultural relationship with natural resources like forest, conservation measures have the prospects of realizing their human rights including economic, social, and cultural rights. However, this realization requires responsible actions, transparency, respect and promotion of rights of the local communities, supports for the enjoyment of such rights, and accountability [1]. At the same time, the exclusionary nature of conservation measures can undermine the rights of the dependent 
communities [28]. The conservation community has been highly scrutinized for their inadequate initiatives to venerate and uphold human rights $[26,29,30]$.

According to the Report of the Special Rapporteur on the issue of human rights obligations relating to the enjoyment of a safe, clean, healthy and sustainable environment (p. 3) [31],

"The full enjoyment of human rights, including the rights to life, health, food and water, depends on the services provided by ecosystems. The provision of ecosystem services depends on the health and sustainability of ecosystems, which in turn depend on biodiversity. The full enjoyment of human rights thus depends on biodiversity, and the degradation and loss of biodiversity undermine the ability of human beings to enjoy their human rights".

The most comprehensive guideline to establish the fundamental principles of human rights is set by the Universal Declaration on Human Rights (1948). It was further strengthened by various international, regional, and national level conventions, treaties, declarations, and guidelines. The 1972 Stockholm Conference on the Human-Environment acknowledges the interconnected relationship between human rights and environment proclaiming that "both aspects of man's environment, the natural and the man-made, are essential to his well-being and to the enjoyment of basic human rights- even the right to life itself" [32]. The International Covenant on Civil and Political Rights (ICCPR) protects individual's rights to life, freedom and performing cultures against violations by the state parties. The International Covenant on Economic Social and Cultural Rights (ICESCR) hallows the rights to decent job, freedom from hunger, rights to work, social rights, and rights to healthy life to name a few. Declaration on the Right to Development (1986) recognizes that "development is a comprehensive economic, social, cultural and political process, which aims at the constant improvement of the well-being of the entire population and of all individuals on the basis of their active, free and meaningful participation in development and in the fair distribution of benefits resulting therefrom" [33].

The Convention on Biological Diversity (CBD) (adopted in 1992 and entered into force in 1993) addresses rights of indigenous and local communities in the context of conservation. Article $8 \mathrm{j}$ of CBD requires that States Parties shall ("as far as possible and as appropriate") "respect, preserve and maintain the knowledge, innovations and practices of indigenous and local communities embodying traditional life styles relevant for the conservation and sustainable use of biological diversity." Article 10(c) instructs the States Parties ("as far as possible and as appropriate") "protect and encourage customary use of biological resources in accordance with traditional cultural practices that are compatible with conservation or sustainable use requirements" [1].

The United Nations strategic plan for forests 2017-2030 (UNSPF) is a framework document for the implementation of relevant laws and conventions like the Paris Agreement, the Convention on Biological Diversity, the United Nations Convention to Combat Desertification, the United Nations Forest Instrument (UNFI), and other national and regional tools and strategies [34]. These strategic documents emphasize the realization of people's dependency over forest (e.g. subsistence, livelihood, employment, and income generation) while designing and implementing conservation measures. Among its six goals, the second goal of the Global Forest Goal is about enhancing the benefits from the forest for the forest dependent people [35]. The Durban Accord adopted in the 5th World Parks Congress in 2005 asks for the commitment of the states and other responsible stakeholders to include the people who get benefit from or are impacted by protected area in decision making process.

The Forest Investment Programme of Government of the People's Republic of Bangladesh includes important measures to secure rights of the forest-dependent communities. The primary aims of the Forest Investment Programme are to ensure biodiversity conservation, protection of the rights of dependent communities, poverty reduction, and improvement of rural livelihoods. The Draft Forest Policy 2016 mentions traditional rights including social, economic, cultural, and religious values of forest dependent people [17]. The Bangladesh National Conservation Strategy (2016-2031) acknowledges the need of developing alternative livelihoods, extending the Payment for 
Ecosystem Service (PES) and highlighting human rights issues of the forest-dependent community [36].

\section{Materials and Methods}

\subsection{Study site}

The links between the realization of the rights of forest-dependent community and the conservation of natural resources are receiving attention worldwide. However, plenty of evidence shows that such conservation efforts undermine rights of the dependent communities. Almost all the available literatures are focused on indigenous and tribal population. Very little attention has been given to the dependent communities living in and around mangrove forest or aquatic forest. Available literatures on mangrove forest- or aquatic forest have discussed about the livelihood status of dependent communities in general $[37,38]$. However, their lives, livelihoods and experience and security in relation to national and international human rights framework are yet to be explored. Unlike other forest, mangrove forests are not inhibited by human. For example, the Sundarban Reserved Forest, a mangrove forest in Bangladesh is the primary and, in many cases, the only means of livelihood to many people living around the forest. Although illegal, local inhabitants collect fuel wood, timber, and fodder requirements from the forest due to poverty and lack of sustainable alternative livelihood options [39,40]. This study sheds light on this unexplored issue about the transition of life and livelihood as well as rights of mangrove forest-dependent people. To do so, Sundarban Reserved Forest in Bangladesh was selected as a case study. My prior familiarity and convenience to reach the study participants also influence site selection.

The Sundarbans mangrove forest, which is the largest mangrove forest in the world, lies on the delta of the Ganges, Brahmaputra, and Meghna rivers on the Bay of Bengal. This great coastal ecosystem covers an area of about 1mha; spreading over Bangladesh and India. The current study was conducted in a forest-dependent community named Hodda, situated within the Sundarban Ecosystem. Hodda is geographically situated in the South-Western part of Bangladesh. From administrative point of view, it is in Maheshwaripur union under Koyra Upazilla of Khulna district.

\subsection{Design}

The study inquired real life contemporary phenomenon along with legal and historical evidences in relation to human rights status and transformation of the livelihoods of forest-dependent community. For that purpose, this study used critical ethnographic method. Critical ethnography is a relatively new approach using insights and tools from conventional ethnography and useful "to explore and understand dominant discourses that are seen as being the 'right' way to think, see, talk about or enact a particular 'action' or situation in society and recommend ways to re-dress social power inequities" [41,42]. In human rights focused research, critical ethnography draws lived experience thinking that human rights obviously affect people in general [43].

The study involved diverse methods like individual in-depth interviews, focus group discussions, and case stories/studies? since using multiple sources of evidence in qualitative research helps to better understand and triangulate of the evidence [44].

\subsection{Data collection}

This study was conducted from March to June 2019. Data were collected from community people, service providers, and policy end. Focus group discussions (FGDs) with male community members aimed to understand the changes in their lives and livelihoods due to conservation measures. The reason for not including any female community member was that this study did not have any specific objective to see gender dynamics and only men were found to be associated with forest dependent livelihood options. On the other hand, in-depth interviews (IDIs) with service providers and policymakers like NGOs and other development organizations tried to understand 
alternative livelihood options for the dependent-community and how their activities comply with national and international human rights framework and policies like the ICESCR and ICCPR.

Participants were selected through a purposive sampling strategy. Five IDIs and six FGDs were conducted using semi-structured guideline. FGD participants included people who used to go to forest or are currently going. Four case stories were also collected focusing on different human rights related issues. In addition, extensive literature review was done to understand the policy and legal context as well as to triangulate with relevant scholarly works.

\subsection{Data analysis}

All the interviews and discussions were digitally recorded and transcribed verbatim. All the transcripts were then coded and analyzed using qualitative content analysis method. Texts from both interviews and discussions were analyzed using the same matrix. To structure and deduce the communicable meaning of the transcribed text, it was organized in a matrix. After completing the matrix, thematic narratives were prepared.

\section{Results}

Data presented below were collected using FGDs, IDIs, and case stories. FGDs and case stories included men aged over 18 years who are currently or previously involved with Bada. IDIs included representatives from government and NGOs. In this study, the term "Bada" has been used to indicate forest-dependent activities. In local terms, "Bada" means going to forest to collect diverse resources including timber, fuel, honey, furniture materials, rooftop materials, fish, prawn larva etc. Local people call Sundarban as "Badabon", which indicates forest where both low and high tide occurs.

\subsection{Involvement with Bada and other Livelihood Activities}

Most of the participants from FGDs and IDIs mentioned their involvement in brick factory and shrimp production as their current primary occupation. Working options depend heavily on seasons. Other major sources of income were working as a day laborer and pulling van, migrating in city areas etc. Still there were considerable numbers of people who used to go to forest for livelihood purpose. But that was no longer their primary source of income. Findings showed a complex relational matrix regarding people's current profession, their dependency over forest and other associated factors. For example, there are many people who used to go to forest to fish in different channels. This practice was dependent upon having a usable boat. In order to make the boat usable, people needed to cut down Golpata (Mangrove Palm), Sundri (Heritierafomes), Gewa (Excoecaria Agallocha), Keora (Sonneratia Apetala), Baen (Avecennia officinalis), Dhundul (Xylocarpus Granatum), and Passur (Xylocarpus Mekongensis) trees. Government put a ban on cutting down these trees under conservation. As a result, people started experiencing troubles regarding fishing activities.

There was a time when collecting timber was the major source of income in the study community. It has been more than ten years that government stopped giving the permission to the dependent people to collect timber. According to the study findings, in practice, people go to forest to collect honey, crabs, fish and sometimes mangrove palm, but in low scale. Livelihood was their primary purpose to collect resources from Sundarban. This included selling those resources in the local market and fulfilling personal needs. People used varieties of trees like Gewa and Goran as fuel. Suddenly (at the beginning of 21st century) government stopped letting them cut down these trees. In case if government let people collect fuel, it required at least 5000 Bangladesh taka (approx. USD 60) to get the permission.

\subsection{Changes in Bada and its Impact on Dependent Communities}

Nature and process of visiting Bada has been changed significantly over the last decade. For example, the government used to provide permission to the people for 25-30 days to go to forest during honey collection season. Pansi and Sampan (type of boat having a covered place in the middle to live on) 
were used frequently. Then suddenly during early 2000s, the government banned the use of these kinds of boats. People could stay as long as they wanted back then, because they did not have to think about accommodation. They had their own accommodation arrangement on the Sampan and Pansi. At one-point, the government made the rule to give permission for only 5-7 days and they were allowed to take only uncovered boat (having no place to live on). Basically, the government did not want people to stay for a longer period inside the forest. That is why they prohibited using boat with living arrangement. In addition to this, frequency of being kidnapped by robbers was also found high while on Bada. As a result, many people of the dependent community stopped going to the forest. They rather preferred working as a day laborer, van puller, working in paddy field, working in brick factory etc. These types of works required hard work, but the benefit was less compared to Bada. One of the FGD participants (32) said-

"If people can go to Bada, stay longer period; the income is handsome. No other profession is as profitable as Bada. But people are leaving this profession because of insecurity. Who wants to get beaten or kidnapped?"

In addition to this, forestry range office, i.e. the designated local government authority, stopped giving pass to cut down timber. Community people argue that there are many trees inside the forest which need to be cut down. Otherwise, it will be dead within the next 2-3 years and eventually rotten and unused. Use of net for fishing was also found prohibited. Many people used to run their livelihood by collecting prawn larva in different channels inside Sundarban, which was found mostly not in practice anymore. One of the FGD participants (29) said-

"Government has banned all of our livelihood activities. Honestly speaking in this country benefits are only for the advantaged and powerful people, which is kind of "gheray knondo khay" (a local Bengali proverb which literally means "crops are grabbed by the fence as well as protector")."

This study also found reverse opinion from few community people through FGDs. One of the participants (39) mentioned that-

"We were not getting adequate benefits from the forest for a long time. People were trying alternative options. I started going to brick field leaving Bada totally. The rule of working in a brick factory is that- you can work there for six months continuously. I earn around 1 lakh taka (approx. USD 1200) in one season (6-months). This amount is much higher than going to Bada, although working in brick field requires lot of hard work. Now, I can even save some money after fulfilling family expenses."

A local government representative presented this trend of becoming less dependent on forest in a different way. According to him-

"It's true that most of the people in this area were completely dependent on forest once. But this dependency is decreasing day by day. Nowadays, most of the people rely on something else instead of Bada. Lots of better opportunities (e.g. shrimp cultivation, working as day laborer, pulling van/rickshaw, working in brick factory etc.) are emerging, which are financially more beneficial."

Participants from focus group discussion argued that these changes took place in the name of forest conservation and environmental protection. A team of forest experts came to assess the status of Sundarban. Before leaving, they developed some rules and regulations including where to go in the forest, where not to go, what resources can be collected, how long people can stay, prohibiting cutting down trees, not to collect timber and other household materials, and even not to fish in most of the water sources within the forest. Authority defined places within the forest where people can go, rest of the places are protected. No one was generally allowed to access the protected areas. 
Although, Bada is no longer people's primary or only livelihood option; study findings found that most of the participants still feel deeply about going to forest and spending 2-3 months there. One of the participants (38) said that-

"They (authority) do not let us go to forest frequently and for longer period thinking that we are threat to the forest. Reality is- we love the forest and trees. We only cut down what we need."

This statement is supported by another participant from a different FGD, where he (42) argued that: "Why would we cut down the trees? We are alive because of this forest and trees. We know better which trees to be cut down or how many trees can be cut down. We always have to think about the enrichment of the trees."

On the contrary, local government representative (union parishad member) described this emotional attachment of community people with forest in a way contrasting to community people's perception. He said-

"It's true that people do harm to the forest by their irresponsible activities. At the same time, forest is still one of the major sources of income for them. If you ask me, I would say that I know better what people of this community do after going to the forest. They take pass for honey collection, but cut down trees in an imprudent way. Since government is being more and more strict on this, people are looking for alternative options".

Study found that people started working as a day laborer, working in brick factory, pulling van/rickshaw when they stopped going to Bada. But those activities were financially insecure for them and required lot more hard work compared to Bada. For example, in brick factory, workers had to work from dawn to dusk without any rest, except two small breaks for having food. On the other hand, people used to get money on a daily basis in day laboring. Sometimes, they did not have any work. As a result, running the family became harder for them. A 39-years old FGD participant explained the situation as follows-

"Basically, we find it hard to work in other field apart from Bada. We are used to this type of work for a long time. Besides, these new types of works require us to work longer period a day and having less food. Leaving Bada is disadvantageous in every way. When there was high time of Bada, we used to work 3-days and could eat for the following 7-days without any tension. Now, if we don't work for a day, we have nothing to eat".

Another FGD participant also expressed the same. According to him-

"People who are still young can somehow manage the situation. The worst victim is the group who were involved in Bada from the very beginning of their working career. We always feel like going to Bada. Believe me, when you will go there you won't feel (scared of being kidnapped or being attacked by tiger) scared or isolated; you will feel like you are in your mother's lap".

A 51 year old person supported this issue by saying that-

"Kidnapping and robbery has been decreased nowadays. But we are facing some other challenges. There is a new organization named Wild Team (an international NGO working on conservation, biodiversity and sustainable livelihood), which has come to work here in Sundarban. They have developed new rules and prohibited all sorts of activities related to Bada in the name of saving the forest."

Few of the participants mentioned about the wastage of resources they possessed. Many people had boat, fishing net, honey collection materials etc. Unfortunately, they were unable to utilize those resources. Sometimes, they had to spend a lot of money for those resources. For instance, fishing net and 
boat were expensive. Considering people's socio-economic status, it was a great shock for them not being able to use them. One FGD participant (46) said-

"I have lots of fishing net worth quarter a million taka (approximately USD 3000) in my house. It has no use, although I could become solvent using this net. Few more people could also become solvent working with me. But I cannot use the net because I do not have fishing pass. There are many more people like me in this area. Our assets are being wasted due to corruption and problematic rules".

\subsection{Existing Rules and Regulations}

Study findings revealed ranges of rules and regulations in relation to stopping and restricting people's access to forest resources. Most of the areas were completely restricted for people. Some people could go there by paying some bribe to the law enforcement agency. However, the site, number of days, and resources to be collected was found to be pre-defined. One area was not possible to access regularly according to the new rule. There was a roaster system in place dividing the accessible forest areas in clusters. This cluster and roaster system was managed by forest rangers. Unfortunately, the lack of coordination was found among the rangers. As a result, if people took permission from one range, other ranges could throw them away or brought them under financial penalty. Participants argued that the worst case used to happen when law enforcement agency caught people inside the forest. People were sent directly to the local police station and in this type of situation the average duration of imprisonment was found 1-2 years. One case was found where the accused was sentenced for 12 years for cutting down tree despite of strict law against it. Some of the participants mentioned about hide and seek method in order to go to forest. It means going to forest without the knowledge and surveillance of authority. When forest was not divided into clusters and there were no rules or prohibition, people could go to the forest wherever they wanted to go. During that time, they knew very well where to go in which season. In the current situation, people who went to the forest to collect honey or prawn larva had to go to places where authority told them to go. Most of the participants mentioned the issue of not having any choice or freedom in terms of choosing resource collection sites and duration.

Forest Rangers, NGO representatives and local government representatives agreed to the information that existing rules and regulations were restricting people's rights and affecting their livelihood in a negative way. They all highlighted the needs of making a balance. One of the Forest Rangers said that:

"People, who are still significantly dependent on forest, consider these rules and regulations as a tool of violating human rights. Because these rules and regulations do not let them do whatever they want to do. They must follow some rules and regulations. Otherwise, they are punished or financially penalized. On the other hand, we have to save the forest for long term benefits. In my understanding, this type of conflicting scenario will not be abolished overnight. We have to go through this."

\subsection{Transaction of Money and Power Relations}

Community people mentioned about bribe culture with emphasis as one of the biggest problems considering their vulnerable socio-economic condition. People had to provide bribe to almost all the members of law enforcement agencies. One 34 years old FGD participant said that:

"Coast Guard members take even 10 taka as bribe. I have given this amount by my own hand any times. I have sent fish to the officers of Coast Guard in thermocol fish box. People who have lots of money give handsome amount to the Coast Guard. The only thing is that, you have to enter into the forest. Once you are there, you can do anything. Since we do not have enough money, we cannot give them big amount to the permission granting authority. The situation is like- no one has anything to do if poor people die. Fishermen are remaining 
fishermen with debt of around 1 million taka (USD 12500). Even law is also against us, because we cannot give money."

The majority of the participants mentioned about the issue that authority did not provide any benefits to the people without bribe. At the same time, there was no platform where people could complaint about the malpractice. Many people went to the local government representatives (UP Member) but did not get any solution. People were threatened to be excluded from the list if they complain. Several national and international NGOs were found working in the study area focusing mainly on livelihoods of the community people. Their work was not exclusively on forest dependent communities, rather providing alternative livelihood and livelihood security of the dependent communities was one of their key working areas. NGOs in collaboration with the government issued some card for the local fishermen. Unfortunately, none of the study participants received that card. Even, they did not hear anyone eligible within their network received that card. All the cards were provided to the solvent people who were involved with some other works.

\section{Alternative Livelihoods}

Providing alternative livelihood option is one of the key rights-related issues in terms of conservation activities according to national and global frameworks. From that perspective, people of the studied community were supposed to be introduced with some kind of alternative livelihood options since either they stopped going to the forest or their access were restricted. This study wanted to understand this fact in details. Study findings revealed that most of the participants were aware of this system. Unfortunately, the majority of them said of getting nothing. Representatives from different NGOs came to them to make list of people who were dependent on forest resources. Listed people were supposed to get some financial support in order to start small scale business. Study participants were found completely unaware of the outcomes of that list. Some of them showed their suspicion. According to a 36 old FGD participant-

"We don't know what they did with the list. We could not even communicate with those NGO representatives. Who knows may be they provided that support which was grabbed by the local leaders or maybe they didn't provide any support at all."

Another participant (39) from the same FGD revealed a more intriguing issue. According to him:

"I know about some alternative options and people who got received that support. It's not something long-term or permanent, it's seasonal and for short period of time. Problem is- if you want to take that opportunity, you have to provide them bribe of 1000-2000 taka (USD 12-24). Who would a poor man manage that amount? Even, I had to pay around 9000 taka (USD 105) in total to get job as a daily laborer which I am eligible to get without spending a penny.

\section{Stakeholder's Perceptions and Knowledge about Human Rights Framework Related to Forest-Dependent Community}

Different stakeholders were asked about national and global human rights framework related to forest dependent community. They couldn't mention about any framework, but they were found aware about the major human rights indicators, such as- freedom of choosing occupation, alternative livelihood options, social dignity, restriction of access, economic solidarity, participation in decision making, participation in conservation activities etc. One of the Forest Rangers explained this issue as:

"Government cannot just avoid human rights issues. People are always the first priority. Even this restriction and prohibition are also for the betterment of the people. Government thinks about long term betterment, but people want instant benefits. This is the major problem. If we have to prioritize their rights all the time, then there will be no forest. Besides, they often violate rules and regulations. Government must take strong steps against these violations. We all have to understand that, forest is like our mother. Our safety and security largely depend on the forest. So, they have to cope-up with this restrictions and regulations." 
NGO representatives mentioned about shared role of people and stakeholders towards conservation. They were working towards raising awareness among the people in order to create a balance between restrictions and livelihood. Their aim was to bring both people and stakeholders in the same line. For example, a personal from an NGO working in the studied community explained:

"The existing situation is not in favor to implement national and global human rights framework. In one hand, we have to make people aware about sustainable and responsible use of forest resources; on the other hand, government also has to be sensible about them. Because, they have been living here for a long time and forest is their main source of income. As a result, implementing some rules and regulation out of nowhere cannot be a good practice. Best practice would be to involve people in conservation measures."

\section{Forest Conservation Activities and People's Participation}

Study revealed zero knowledge among the community people about forest conservation measures in general. No one ever told them about this. In addition, they revealed that they never heard about it through media (e.g. TV, radio, newspaper). Participants were further asked about participatory conservation measures and their level of involvement as a part of probing approach. This time some of them said correctly about participatory conservation measures. According to a FGD participant (37)-

"I think participatory conservation means protecting the forest together. But we can neither go there nor get information about it. If we are not informed or called upon, how do we know? We all want to save the forest, but not by depriving ourselves. We want both us and the forest to be alive."

This study showed that people from dependent community apparently were not involved in any steps of contextualizing or implementing any such rules and regulations. In focus group discussions with community members, participants highlighted repeatedly about the negative impact of existing rules and regulations. According to one of the FGD participants:

“These rules and regulations are violating our rights, destroying our income earning options. Bada is our primary livelihood option. We are familiar and skilled in Bada. This is our ancestral occupation. If government wants to ban this by imposing rules and regulations, it's kind of killing people by snatching their food."

This lack of knowledge and awareness were found to lead to some bigger issues. Some of the community people mentioned about punishment as the source of information regarding forest conservation. They argued that people come to know about rules and regulations when they get caught. Besides, there were no initiatives from government to make them aware or to inform them about the rules and regulations. Despite this information gap, punishment and imprisonment as well as transaction of money were found to be a common case. Initial literature review also identified the provision of punishment in case of violating rules and regulations. FGD participants described how punishment and transaction of illegal money impacted their life negatively. Participants also mentioned about honey collector's dishonesty as well. Sometimes, people themselves are responsible for their imprisonment. One FGD participant (43) described this issue as follows-

"Honey collectors bring sugar to the forest. After collecting the honey, collectors mix sugar in it in order to increase the volume. Sometimes, they mix 10-kgs of sugar in 1-kg of honey. Ultimately what happens is- there is no honey there. Besides, honey works as a remedy for many diseases. When you will mix other ingredients in honey, it will not work properly. If law enforcement finds it, people get punishment. There are plenty of examples of this kind of incidents. Basically, we are doing harm to ourselves. This is our income earning option. If we become dishonest, this industry will ruin for sure."

At the same time, people mentioned about some reasons behind that dishonesty. One of the participants from FDG said that: 
"People are bound to do so in a sense. Previously, people could collect honey from all over the forest. They never became dishonest during that time. Now, the area has been limited. They cannot collect adequate amount of honey from the permitted area. That's why they are being dishonest."

In order to prevent the conflicting situation, government and other stakeholders organized workshops to raise awareness among them as well as to inform them about the rules and regulation. Some of the FGD participants and stakeholders mentioned about this awareness raising activities. All such session was on sustainable honey collection. Honey collectors were debriefed about the rules and regulations of collecting honey. Study found a consensus among the participants that, resources have been decreased in the forest. Most of the participants agreed to the rules and regulations of restricting their access in order to save the forest, but not leaving them in impoverishment and destituteness. There should be some balance. One of the key measures could be to ensure sustainable alternative livelihoods. At the same time, all sorts of corruption and malpractice need to be eradicated through proper actions. Later, people might be provided the chance to go to forest again. On the other hand, participants accused powerful people for most of the illegal resource collection with the help of law enforcement agency.

\section{Discussion}

Due to geographic position, people of the study area are historically dependent on forest for their livelihood. About 20-30 years ago, dependency over the forest was much higher. Almost all the people were completely dependent on the forest. They did not have any other major income sources. The context has been changed a lot with the transition of forest resource collection as people's primary source of income. The reasons behind this transformation include enforcement of conservation rules and regulations, kidnapping, robbery, provision of punishment etc. But it's not like people are no more dependent on forest. Many people are still dependent on the forest, but partially. Forest cannot fulfill their demand entirely. They have to get involved with other economic activities. Although few people were doing good getting involved with alternative options, still they had deep feeling for the forest. In addition, lot of people from that community was still entirely dependent on forest.

Findings of this study reveal a paradoxical pattern of understanding and experience from both community people and stakeholders including representatives of local forestry department, local government and NGOs. In one hand, community people accused newly imposed conservation rules and regulation from government behind their impoverishment. On the other hand, stakeholders also acknowledged that people were facing different types of problems related to livelihood, socio-economic security and so on due to conservation related activities. They mentioned about two seemingly conflicting issues- strict rules in terms of forest conservation and violations of rules by community people.

This study did not intend to evaluate the application or status or contextual perception of any specific human rights frameworks related to conservation or forest management. Rather, it tried to explore some of the basic aspects of human rights. Insights related to the rights of the people affected by conservation measures have been taken from Universal Declaration of Human Rights, ICESCR, ICCPR, CBD, Stockholm Conference on the Human-Environment and other major human rights frameworks including national guidelines. Some of the core human rights indicators derived from these frameworks include social and economic aspects; livelihood security; freedom of choosing income earning option; right to information; right to participation; consent taking and right to complaint; right to enjoyment of full benefits from forest and not being abused by poor and malfunctioning governance.

Since a safe, clean, healthy and sustainable environment is undeniable for the full enjoyment of human rights as mentioned in Framework Principles on Human Rights and the Environment; conservation becomes a topmost priority [2]. But that does not mean to overlook people living in conservation areas. Evidence of denials of rights of the people living in conservation area like 
Sundarban Reserved Forest is not scarce. Study findings discuss implementation weakness and violations of human rights in the studied forest dependent community.

Study shows zero knowledge among the community people about the importance and implementation of conservation rules and regulations in protected areas like Sundarban. They accused that they were just forced to follow the rules and regulations. No one from either government or NGO's ever came to them in order to sensitize them on the issue. On the other hand, stakeholders from local forestry office mentioned about providing training to the shrimp larva collector following the latest guidelines covering the contents like- when to catch shrimp larva, what type of instruments to be used, how long they should stay in different rivers and channels inside Sundarban etc. So far, no initiative was undertaken to raise awareness among the dependent community or to include them in the conservation process. But community participation in conservation activity is one of the key indicators to ensure their rights. This study did not find any evidence of participatory conservation activities. At the same time, rights to information were also not found in practice. People of forest dependent community were not informed about the rules and regulations. They only way they came to know about the information were when they seek permission or being arrested.

Explain why you suddenly mentioned about women here. In case of women, conservation activities completely ignore women, whereas they are also a key part of conservation activities. They also get affected by conservation measures and in many places, they perform major economic activities. Some studies showed positive outcomes of integrating women in conservation activities. A study conducted in Nepal and India showed that having high proportion of women in decision making role in community based conservation committee helped to achieve greater improvements in forest condition [45]. The same study found in Nepal that, despite of getting smaller and vulnerable forests compared to male, all-women executive committee had better forest regeneration and canopy growth. Leisher et. al. showed that inclusion of women in natural resource management resulted better outcomes [46]. According to the mainstream narratives, men play a greater role than women in exploring natural resources for commercial purposes. Women normally take care of household chores. Activities of women living in protected areas or buffer zones of protected areas include cooking, water and fuel wood collection, child care, etc. These activities are often ignored from economic point of view. But women take the leading role in community management by controlling the consumption patterns, collecting fire woods and providing tradition healthcare services using forest resources [47].

Security of life and livelihood is an indispensable factor in every framework talking about human rights. Findings of the study help to unpack the ground level truth about the realization and implementation of human rights issues in conservation measures related to life and livelihood of the people of dependent community. While government is enforcing conservation measures with utmost importance, study reveals that the security of people's life and livelihood is not considered at all. Researchers from around the world have observed livelihood insecurity as one of the major concerning issues of strict conservation activities [48,49]. People who lose their access to forest resources are responsible for their own rehabilitation and sustainability. This study reveals vulnerability and instability of the studied community. But this is not a unique case. A study conducted in India by Sarangi (2017) showed 62\% unsettled cases of forest rights and land rights in the Indian wildlife protected areas [50]. In another study, Rao (2004) argued about the adverse effects of conservation on livelihood. He showed that, before the Satkosia wildlife sanctuary was declared as protected area, average monthly household income was INR 5000 (USD 72) which dropped by more than $50 \%$ as soon as people's access to forest resources became restricted [51].

Corruption can be a major indicator behind the violation of rights of the forest dependent community. Study found large scale corruption and unequal power relation, such as- taking bribe to give permission to enter into the forest, harassment by law enforcement agencies, not to let the people using their traditional ways of fishing and shrimp larva collection etc. According to the rule, a certain amount of money needs to be paid in order to get permission to go to the forest. This temporary licensing amount varies depending on the duration and types of resources to be collected. 
But all the participants from the community mentioned that they needed to pay extra amount to get the permission. While inside the forest they were required to pay to the patrolling law enforcement agencies. If they did not agree to pay the money, their instruments and materials for resource collection were seized and sometimes they were arrested. For this kind of incident, representatives from local forestry office and local government institution mentioned about violation of rules and staying overtime inside the forest. This corruption, abuse and victimization is common in many protected areas around the world. A most recent case found serious human rights violations including physical abuse and killings by rangers and stewards responsible for carrying out conservation activities [52].

Analysis of the findings clearly indicates poor management to ensure alternative livelihood options for the affected people, although it is one of the major approaches to save dependent communities from the detrimental effects of conservation, as well as to reduce local level threats to species, habitats or resources of conservation concern; which help to ensure a balance between conservation and rights related to life, livelihood and descent work [53-55]. This particular criterion of poor management has been highlighted by researchers around the world. Researchers have expressed their concerns that the alternative livelihood approach maybe flawed considering the diverse and mixed livelihood practices of natural resource dependent communities [56]. Findings also show penetration of such rights due to unequal power relations, lobby and transaction of money. In one hand the availability of alternative livelihood options was inadequate considering the needs. On the other hand, people who were supposed to get those benefits were often deprived. Analysis shows that rich and powerful people control the overall forest resource collection process. This unequal practice couples people suffering and make their livelihood transition more miserable.

Taking all the aspects into consideration, a crucial question may arise in terms of setting priority among conservation strategies, rights of the dependent community and combination of both. The best practice should be to incorporate rights-related issues while designing and implementing conservation measures as suggested by UNSPF [34]. This study found conservation as the first priority. In practice, the national level policies and strategies like 7th Five Year Plan of Bangladesh, Forest Policy, Bangladesh national Conservation Strategy and Forest Investment Programme emphasize on the rights of the dependent community as a secondary issue. Certainly, rights of the people living in conservation areas have not been mainstreamed.

\section{Conclusions}

Dynamics of forest dependent communities in Bangladesh context are very complex. Study findings provide a clear image of instability, transition and vulnerability of the studied forest dependent community. All the changes started with various conservation measures implemented in Sundarban protected area. Different human rights frameworks have been developed globally in order to prevent the adverse effects of conservation measures on local communities and to upkeep their rights. Since, there is still significant amount of contestation over the scope of human rights and how human rights are realized in conservation measures; the current study tried to contribute in that regard by understanding the impact of conservation measures from both community and implementer's point of view using the lens of human rights taking a Sundarban mangrove forest-dependent community as case.

In one hand, dependent community's experience and their livelihood transition is in conflicting situation with conservation. On the other hand, structured approaches like CBD, ICESCR, ICCPR etc are not properly realized among the implementing stakeholders. Considering this context, a debate as argued by Conroy and Peterson (2013) between scientific or structured method of conservation and forest management and ad hoc nonscientific method of management cannot be avoided [57]. Future research demands this issue to be encountered.

In spite of vigorous global advocacy on increasing government and other conservation organization's efforts to better realize the rights related issues while implementing conservation measures; still the findings of this study reveals significant shortcomings in terms of balance 
between affected community and implementing institutions. A balance between conservation measures and relevant human rights frameworks is mandatory to ensure sustainability and wellbeing of dependent communities and forest as well as the environment. Human rights protection needs to be incorporated and mainstreamed in all sorts of measures related to biodiversity protection, forest conservation, environmental protection etc. Thus, the foundation will be developed where forest dependent communities and implementing organizations will become allies, rather than becoming each other's opposition.

Funding: This research received no external funding, but mentorship only from Raoul Wallenberg Institute of Human Rights and Humanitarian Law (RWI).

\section{Acknowledgments:}

This study was conducted under Regional Human Rights Research Initiative 2019, Raoul Wallenberg Institute of Human Rights and Humanitarian Law (RWI). The author is grateful of being selected in this program. The author thanks Dr. Claudia for her guidance and precise feedback in every steps of the study, from conceptualization to finalization of this paper. Special thanks to Taybur Babu for his support and time during data collection and transcription phase. The author also like to thank Ms. Socheata Sao and Ms. Pramila Ramtel for their constructive feedback on grammar, sentence formation and structure of argument.

Conflicts of Interest: The author declares no conflicts of interest.

\section{References}

1. Springer, J.; Campese, J.; Painter, M. Conservation and human rights: key issues and contexts. Scoping paper for the Conservation Initiative on Human Rights; 2011;

2. Knox, J.H. Human Rights, Environmental Protection, and the Sustainable Development Goals. Washingt. Int. Law J. 2015, 517.

3. Gogoi, L. Degradation of natural resources and its impact on environment: a study in Guwahati City, Assam, India. Int. J. Sci. Res. Publ. 2013, 3, 1-7.

4. Pawar, K. V; Rothkar, R. V Forest Conservation \& Environmental Awareness. Procedia Earth Planet. Sci. 2015, 11, 212-215.

5. Innes, J.L. Forests in Environmental Protection. For. For. Plants 2007, 1.

6. IUCN IUCN issues briefs. November 2017,.

7. Mbuvi, D.; Boon, E. The livelihood potential of non-wood forest products: The case of Mbooni Division in Makueni District, Kenya; 2008; Vol. 11;.

8. Weisse, M.; Goldman, E.D. Global Tree Cover Loss Rose 51 Percent in 2016 Available online: https://www.wri.org/blog/2017/10/global-tree-cover-loss-rose-51-percent-2016 (accessed on May 24, 2019).

9. Khokhar, T.; Tabary, M.E. Five forest figures for the International Day of Forests Available online: https://blogs.worldbank.org/opendata/five-forest-figures-international-day-forests (accessed on Jun 4, 2019).

10. Frey, S.J.K.; Hadley, A.S.; Johnson, S.L.; Schulze, M.; Jones, J.A.; Betts, M.G. Spatial models reveal the microclimatic buffering capacity of old-growth forests. Sci. Adv. 2016, 2, e1501392.

11. Potter, B.E.; Zasada, J.C. Biomass, thermal inertia, and radiative freeze occurrence in leafless forests. Can. J. For. Res. 1999, 29, 213-221.

12. Graw, V.; Nkonya, E.; Gerber, N.; Baumgartner, P.; von Braun, J.; De Pinto, A.; Edward, K.; Kloos, J.; Walter, T. The Economics of Land Degradation. Toward an Integrated Global Assessment; 2011; 
13. Veldkamp, A.; Lambin, E.F. Predicting land-use change: editorial. Agric. Ecosyst. Environ. 2011, 85, 1-6.

14. Zhu, J.-J.; Li, F.-Q. [Forest degradation/decline: research and practice]. Ying yong sheng tai $x u e$ bao $=J$. Appl. Ecol. 2007, 18, 1601-1609.

15. Tauli-Corpuz, V.; Alcorn, J.; Molnar, A. Cornered by Protected Areas: Replacing 'Fortress' Conservation With Rights-Based Approaches Helps Bring Justice for Indigenous Peoples and Local Communities, Reduces Conflict, and Enables Cost-Effective Conservation and Climate Action. Rights Resour. Initiat. wwww. corneredbypas. Com/br. 2018.

16. United Nations Convention on Biological Diversity; 1990;

17. BFD Government of the People's Republic of Bangladesh Forest Investment Programme 2017; 2017;

18. Rahman, M.M. Forest resources of Bangladesh with reference to conservation of biodiversity and wildlife in particular for poverty alleviation. In Proceedings of the Proceedings of the workshop on Forests for poverty reduction: Opportunities with clean development mechanism, environmental services and biodiversity. Bangkok: FAO Regional Office for Asia and the Pacific (FAO-RAP); 2004; pp. 139-148.

19. Prespa Ohrid Nature Trust Conflict Assessment in Wider Prespa Area; 2018;

20. Adetoro, A.O.; Oyeleye, D.O.; Ijeomah, H. Causes and Impacts of Conflict on Biodiversity Management at the Buffer Zone of Old Oyo National Park, Oyo State, Nigeria. African Res. Rev. 2011, 5, 485-495.

21. Dewan, G. Conservation and its impact on the rights of indigenous peoples. In Proceedings of the International Expert Group Meeting: Conservation and the Rights of Indigenous Peoples,; United Nations, 2019.

22. iied Conservation Initiative on Human Rights Available online: https://www.iied.org/conservation-initiative-human-rights (accessed on Jun 6, 2019).

23. Balint, P.J. Improving community-based conservation near protected areas: the importance of development variables. Env. Manag. 2006, 38, 137-148.

24. Muhumuza, M.; Balkwill, K. Factors Affecting the Success of Conserving Biodiversity in National Parks: A Review of Case Studies from Africa; 2013; Vol. 2013;

25. González, A.M.; Martin, A.S. Gender in the conservation of protected areas. Innov. Conserv. Ser. Park. Peril Program. Arlington, VA, USA Nat. Conserv. 2007.

26. Colchester, M. Beyond tenure: rights-based approaches to peoples and forests. Some lessons from the Forest Peoples Programme. Beyond tenure rights-based approaches to peoples For. Some lessons from For. Peoples Program. 2007.

27. Shelton, D.L.; Greiber, T.; Janki, M.; Orellana, M.; Savaresi, A. Conservation with Justice: A Rights-Based Approach. 2010.

28. Campese, J.; Sunderland, T.; Greiber, T.; Oviedo, G. (eds. . Rights-based approaches: Exploring issues and opportunities for conservation; Bogor, Indonesia, 2009;

29. Alcorn, J.B.; Royo, A.G. Conservation's Engagement with Human Rights: Traction, Slippage or Avoidance? Policy matters 2007, 15.

30. Chapin, M. A Challenge to Conservationists. Worldwatch Institute. Worldwatch Maga 2004.

31. United Nations Report of the Special Rapporteur on the Issue of Human Rights Obligations Relating to the Enjoyment of a Safe, Clean, Healthy and Sustainable Environment; 2017;

32. UN Report of the United Nations Conference on the Human Environment; Stockholm, 1972;

33. OHCHR Declaration on the Right to Development Available online: https://www.ohchr.org/en/professionalinterest/pages/righttodevelopment.aspx (accessed on Jul 14, 
2019).

34. UN United Nations Strategic Plan for Forests, 2017-2030; 2016;

35. UN Forum on Forests Six Global Forest Goals agreed at UNFF Special Session Available online: https://www.un.org/esa/forests/news/2017/01/six-global-forest-goals/index.html (accessed on Jun 4, 2019).

36. IUCN and BFD Bangladesh National Conservation Strategy (2016-2031), Part 1: Executive Summary; Dhaka, 2016;

37. Sarker, K. Fisher Livelihhods in the Sundarbans. In Rural Livelihoods and Protected Landscapes: Co-management in the Wetlands and Forests of Bangladesh; USAID Bangladesh: Dhaka, Bangladesh, 2011; pp. 47-65.

38. Zohora, F.T. Non-timber forest products and livelihoods in the Sunderbans. In Rural Livelihoods and Protected Landscapes: Co-management in the Wetlands and Forests of Bangladesh. Nishorgo Network, Dhaka; 2011; pp. 99-117.

39. Abdullah, A.; Stacey, N.; Garnett, S.; Myers, B. Economic dependence on mangrove forest resources for livelihoods in the Sundarbans, Bangladesh. For. Policy Econ. 2016, 64, 15-24.

40. Chowdhury, M.T.A. Resource-dependent livelihoods in the Sundarbans 2010.

41. Fitzpatrick, K. Why Critical Ethnography? Counterpoints 2013, 432, 25-52.

42. May, S.A. Critical Ethnography BT - Encyclopedia of Language and Education: Research Methods in Language and Education. In; Hornberger, N.H., Corson, D., Eds.; Springer Netherlands: Dordrecht, 1997; pp. 197-206 ISBN 978-94-011-4535-0.

43. McConnell, L.; Smith, R. Research Methods in Human Rights; Routledge, 2018; ISBN 131737374X.

44. Yin, R.K. Case study research: design and methods 5th ed. Thousand Oaks 2014.

45. Agarwal, B. Gender and forest conservation: The impact of women's participation in community forest governance. Ecol. Econ. 2009, 68, 2785-2799.

46. Leisher, C.; Temsah, G.; Booker, F.; Day, M.; Samberg, L.; Prosnitz, D.; Agarwal, B.; Matthews, E.; Roe, D.; Russell, D.; et al. Does the gender composition of forest and fishery management groups affect resource governance and conservation outcomes? A systematic map. Environ. Evid. 2016, 5, 1-10.

47. WEDO Gender and Biodiversity Available online: http://wedo.org/wp-content/uploads/Gender_and_Biodiversity_WEDO.pdf (accessed on Aug 28, 2019).

48. Ferraro, P.J.; Hanauer, M.M.; Sims, K.R.E. Conditions associated with protected area success in conservation and poverty reduction. Proc. Natl. Acad. Sci. U. S. A. 2011, 108, 13913-13918.

49. McElwee, P. Resource Use Among Rural Agricultural Households Near Protected Areas in Vietnam: The Social Costs of Conservation and Implications for Enforcement. Environ. Manage. 2009, 45, 113-131.

50. Sarangi, T. The Forest Rights Act 2006 in protected areas of Odisha, India: Contextualizing the conflict between conservation and livelihood. Asia Pacific J. Environ. Law 2017, 20, 180-205.

51. Rao, Y.G. Livelihood Issues in Satkosiya Gorge Sanctuary, Orissa; 2004;

52. Warren, T.; Baker, K.J.M. WWF Funds Guards Who Have Tortured And Killed People. BuzzFeed News 2019.

53. LEVANG, P.; DOUNIAS, E.; SITORUS, S. OUT OF THE FOREST, OUT OF POVERTY? For. Trees Livelihoods 2005, 15, 211-235.

54. Adams, W.M.; Aveling, R.; Brockington, D.; Dickson, B.; Elliott, J.; Hutton, J.; Roe, D.; Vira, B.; Wolmer, W. Biodiversity conservation and the eradication of poverty. Science 2004, 306, 1146-1149.

55. Roe, D.; Booker, F.; Day, M.; Zhou, W.; Allebone-Webb, S.; Hill, N.A.O.; Kumpel, N.; Petrokofsky, G.; 
Redford, K.; Russell, D.; et al. Are alternative livelihood projects effective at reducing local threats to specified elements of biodiversity and/or improving or maintaining the conservation status of those elements? Environ. Evid. 2015, 4, 22.

56. Mansfield, D.; Pain, A. Alternative livelihoods: substance or slogan?; Kabul, 2005;

57. Conroy, M.J.; Peterson, J.T. Introduction: Why a Structured Approach in Natural Resources? In Decision making in natural resource management: a structured, adaptive approach; John Wiley \& Sons, 2013; pp. 3-12 ISBN 1118506235.

\footnotetext{
${ }^{\text {i }}$ United Nations Framework Convention on Climate Change (UNFCCC):

https://unfccc.int/files/essential background/background publications htmlpdf/application/pdf/conveng.pdf United Nations Convention to Combat Desertification (UNCCD):

http://catalogue.unccd.int/936 UNCCD Convention ENG.pdf
}

ii Goal 2: End hunger, achieve food security and improved nutrition and promote sustainable agriculture Goal 3: Ensure healthy lives and promote well-being for all at all ages

Goal 6: Ensure availability and sustainable management of water and sanitation for all

\section{iii Link to the conventions}

Ramsar Convention:

https://www.ramsar.org/sites/default/files/documents/library/introducing ramsar web eng.pdf

World Heritage Convention: https://whc.unesco.org/en/convention/

Convention on International Trade in Endangered Species: https://www.cites.org/eng/disc/what.php

Vienna Convention: https://ozone.unep.org/treaties/vienna-convention

Indigenous and Tribal Peoples Convention:

https://www.ilo.org/dyn/normlex/en/f?p=NORMLEXPUB:12100:0::NO::P12100 ILO CODE:C169

International Tropical Timber Agreement:

https://treaties.un.org/doc/Treaties/2006/02/20060215\%2004-26\%20PM/Ch_XIX_46p.pdf

Agreement Establishing the World Trade Organization:

https://www.wto.org/english/docs e/legal e/04-wto.pdf 